\title{
BACTERIAL CONTAMINANTS OF OPERATION THEATRE SETTINGS IN PUBLIC AND PRIVATE SECTOR HOSPITALS IN GOJRA.
}

1. BS (Hons) OT Technology OT Technologist THQ Hospital Gojra.

2. $2^{\text {nd }}$ Year MBBS Student RMDC Lahore Cant.

3. MBBS

Medical Officer Peads Surgery

Mayo Hospital Lahore.

4. MBBS, FCPS

Consultant \& HOD Surgery

THQ Hospital Gojra.

Correspondence Address:

Sobia Noreen

Department of Surgery

THQ Hospital Gojra.

Article received on:

29/10/2019

Accepted for publication:

08/01/2020

\begin{abstract}
Sobia Noreen ${ }^{1}$, Muhammad Ibrahim Yamin², Ayesha Ajmal ${ }^{3}$, Muhammad Ajmal $^{4}$
ABSTRACT... The study aims to recognize bacterial colonization of surfaces and equipment's in operation theaters and to determine the bacteriological contamination of air in OTs in Gojra. Objectives: To identify the bacteriological colonization of surfaces, inanimate objects, air, in the operation room facilities and antibiotic susceptibility profile of the isolates at tehsil Gojra hospitals. Study Design: One Group Pre and Post-experimental study. Settings: Department of Surgery THQ Hospital Gojra. Period: 1st January 2019 to 31st July 2019. Material \& Methods: Operation theatres sampled and left vacant for more than one-hour before sampling. Settle pate method used for sampling of air by using agar plates and swab method for sampling of surfaces and equipment. Bacterial isolates identified by colony morphology. Gram Staining, Antibiotic Susceptibility testing done by disc diffusion technique. Conclusion: There is a high hazard for the occurrence of surgical site infections because of the significant level of pollution observed in our study. The results emphasize the need for proper cleaning, scrubbing techniques, improved disinfection and sterilization methods and regular fumigation of operation theatres to prevent the cause of infection and maintain a safe environment for the patients and health care professionals.
\end{abstract}

Key words: Antibiotic Resistance, Bacterial Contaminaions, Operation Theatre, Air Sampling, Swab Test.

Article Citation: Noreen S, Yamin MI, Ajmal A, Ajmal M. Bacterial contaminants of operation theatre settings in public and private sector hospitals in Gojra. Professional Med J 2020; 27(8):1612-1616. DOI: 10.29309/TPMJ/2020.27.08.4299

\section{INTRODUCTION}

Bacterial contamination of the operating theaters (OT) remains one of the major risk factors responsible for increasing the incidence of surgical sites infections and nosocomial infection. Around $10 \%$ of the nosocomial contaminations have genuine results prompting longer term of hospital stay and cost trouble. ${ }^{1}$ The main reason for patient mortality and illness are nosocomial infections. Microbiological surveillance is an important part of an infection control program, providing data concerning types, and numbers of bacteriological flora. ${ }^{2}$ If sterilization of operation theaters is not sufficient, it lead to worse predictive results of post-operative patients due to surgical site infections. ${ }^{3}$

Source of bacteriological contamination is diverse, from surgical/medical team, theater gowns, movement within the units, foot wares, leakage of the wounds, gloves and hands, collection bags and transportation of patients. ${ }^{4}$ The use of high antibiotic, in invasive procedures and due to insufficient infection control and bacterial transmission between the patients might explain why OTs remain "major zone" for the spread and occurrence of bacteriological resistance. ${ }^{5}$

Microbiological testing of inanimate surfaces and equipment by environmental monitoring is an effective method to detect the changing developments of counts and types of bacteriological flora. ${ }^{6}$ To control the numbers and types of microbes, or particulates, in OT air microbiologic air sampling is used. ${ }^{7}$ In health facilities controlling airborne pathogens is not only important for the safety of the patient, but it is also important for hospital. ${ }^{8}$ Like-wise there is no standard strategy for shaving of the patients and sterile shower before coming into the 
theater. Every one of these elements assumes a job in sullying of the working auditorium and ensuing postoperative diseases. ${ }^{9}$ Reduction of bacteriological contamination impact in a hospital setting, depends primarily on developed cleaning and proper decontamination of the hospital environment, especially high-risk areas, as these methods are very important to control the spread of these bacteriological contamination. ${ }^{10}$

Particle counting and microbiological sampling can be accomplished routinely for the assessment of air quality in operation theater. ${ }^{11}$ The clinical suggestion of bacterial contamination in the operating theater and overall outcome on infection control in hospital settings is enormous on both the patient and medical health care workers. On the bases of this observation, we decided to evaluate the level of bacteriological infection in the operating theater settings in Tehsil Gojra.

\section{MATERIAL \& METHODS}

Operation theatres were selected and left vacant for more than one hour before sampling, to avoid false-positive outcomes due to recent theatre usage. The theater doors kept locked earlier to and during the sampling period. ${ }^{12}$

Settle plate method used for sampling of air by using blood agar plates from four OTs, and including one labor room of THQ Hospital Gojra and two private hospital OTs in Gojra. Blood agar plates were kept open in the OTs and at a height of $1 \mathrm{~m}$ and $1 \mathrm{~m}$ from the walls of the rooms. Sampling time was 1 hour.

The contamination of air was measured by calculating the number of CFU (colony forming unit) per cubic meter (CFU/ m3) of air. ${ }^{13}$ CFU count should be $<200 / \mathrm{m} 3$. It is standard for comparison.

Samples were collected from different sites and equipment of four OTs, and one LR and two private OTs. Sterile samples swabs used in nutrient broth to collect samples. They were placed back into the broth after collection. All the samples were labeled properly and immediately transported to the laboratory of the microbiology department of
Government College University, Faisalabad and incubated $37^{\circ} \mathrm{C}$ for 4 hours. Swabs were taken from different sites inoculated on Blood agar and MacConkey agar. These culture plates were incubated at $37^{\circ} \mathrm{C}$ under the aerobic condition for 24 hours. ${ }^{14}$

Bacterial isolates were identified by colonial morphology, gram reaction and standard biochemical tests. ${ }^{15}$ Antibiotic susceptibility testing was done by disc diffusion technique. ${ }^{16}$

\section{RESULTS}

An aggregate of 60 examples were assembled. Tests were gathered from the four operation theaters including general operation theater, gynecology operation theatre, eye operation theatre, and one private operation theatre was likewise included. Tests were gathered by utilizing a settle plate strategy and swabbing technique. Out of 60 examples, 15 examples were gathered from every operation theaters. 8 after cleaning or before the beginning of activities and 7 preceding cleanings or at the end of activities.

Out of 60 examples, 49(81.6\%) yielded positive bacterial development and the remaining $11(18.3 \%)$ were growth negative.

Private operation theater demonstrated the most noteworthy CFU rate of $135 \mathrm{CFU} / \mathrm{m} 3$ and $234 \mathrm{CFU} / \mathrm{m} 3$ in pre and post-operative periods individually and gynecology OT $86 \mathrm{CFU} / \mathrm{m} 3$ and $177 \mathrm{CFU} / \mathrm{m} 3$ in pre and post usable occasions. The least CFU rate was appeared by eye OT and general activity theaters with $35 \mathrm{CFU} / \mathrm{m} 3$ and 82 $\mathrm{CFU} / \mathrm{m} 3$ in pre usable periods and $72 \mathrm{CFU} / \mathrm{m} 3$ and $165 \mathrm{CFU} / \mathrm{m} 3$ in post usable occasions.

The prevalence of gram-positive isolates (60\%) was higher than gram-negative isolated bacteria (21.6\%). The highest percentage of bacteria were from the genus Staphylococcus. Out of these Staphylococcus spp. 25\% (15 out of 60 ) were Staphylococcus aureus and 16.65 (10 out of 60 ) were coagulase-negative Staphylococci (CoNS). Among the Staphylococci, Staphylococcus aureus were the predominant bacteria followed by the CoNS. The second highest bacteria 
isolated were the Bacillus subtilis $16.6 \%$ (10 out of 60$)$. The third highest isolated bacteria were $\mathrm{E}$. coli $10 \%$ (6 out of 60 ) and Acinetobacter spp. (5 out of $60,8.3 \%)$ and Klebsiella pneumonia 3.3\% (2 out of 60) and Streptococcus spp. 3.3\% (2 out of 60$)$.

The most common bacterial genera that were recovered are staphylococcus and Bacillus subtilis.

\begin{tabular}{|l|c|c|c|c|c|c|c|c|c|}
\hline $\begin{array}{c}\text { Sample } \\
\text { Collection Place }\end{array}$ & Wall & Floor & $\begin{array}{c}\text { Suction } \\
\text { Machine }\end{array}$ & $\begin{array}{c}\text { Anesthesia } \\
\text { Machine }\end{array}$ & Bed & $\begin{array}{c}\text { OT } \\
\text { Light }\end{array}$ & Air & Instrument & Grand Total \\
\hline General OT & 2 & 2 & 2 & 2 & 2 & 2 & 2 & 1 \\
\hline Gynecology OT & 2 & 2 & 2 & 2 & 2 & 2 & 2 & 1 \\
\hline Eye OT & 2 & 2 & 2 & 2 & 2 & 2 & 2 & 1 \\
\hline Private OT & 2 & 2 & 2 & 2 & 2 & 2 & 2 & 1 \\
\hline Grand total & 8 & 8 & 8 & 8 & 8 & 8 & 8 & 4 \\
\hline
\end{tabular}

\begin{tabular}{|l|c|c|c|c|c|c|c|c|}
\hline $\begin{array}{c}\text { Operation } \\
\text { theatres }\end{array}$ & $\begin{array}{c}\text { Acineto- } \\
\text { bacter spp }\end{array}$ & $\begin{array}{c}\text { Bacillus } \\
\text { spp }\end{array}$ & CoNS & E. Coli & $\begin{array}{c}\text { K. pneumo- } \\
\text { niae }\end{array}$ & $\begin{array}{c}\text { S. } \\
\text { aureus }\end{array}$ & $\begin{array}{c}\text { Strepto- } \\
\text { coccus spp }\end{array}$ & $\begin{array}{c}\text { Grand } \\
\text { Total }\end{array}$ \\
\hline Eye OT & 0 & $3(5 \%)$ & $2(3.3 \%)$ & 0 & $1(1.6 \%)$ & $3(5 \%)$ & 0 \\
\hline General OT & $1(1.6 \%)$ & $1(1.6 \%)$ & $2(3.3 \%)$ & $2(3.3 \%)$ & $1(1.6 \%)$ & $4(6.6 \%)$ & 0 \\
\hline $\begin{array}{l}\text { Gynecology } \\
\text { OT }\end{array}$ & $2(3.3 \%)$ & $4(6.6 \%)$ & $2(3.3 \%)$ & $1(1.6 \%)$ & 0 & $4(6.6 \%)$ & $1(1.6 \%)$ \\
\hline Private OT & $2(3.3 \%)$ & $2(3.3 \%)$ & $3(5 \%)$ & $3(5 \%)$ & 0 & $4(6.6 \%)$ & $1(1.6 \%)$ & $15(25 \%)$ \\
\hline Grand total & $5(8.3 \%)$ & $10(16.6 \%)$ & $9(15 \%)$ & $6(10 \%)$ & $2(3.3 \%)$ & $15(25 \%)$ & $2(3.3 \%)$ & $49(81.6 \%)$ \\
\hline
\end{tabular}

Table-II. Operation theatre wise distribution of samples $\mathrm{n}=60$ and bacterial isolates from operation theatres.

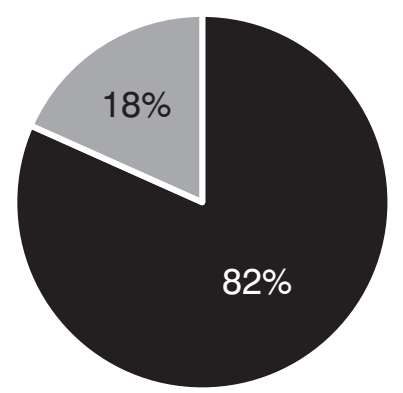

Growth +ve growth -ve

Figure-1. Prevalence in samples.

\section{DISCUSSION}

Qaisar, Akhtar ${ }^{17}$ They conducted a study to estimate the level of bacterial contamination of equipment's, air, and surfaces in operation theaters in tertiary care hospitals in Lahore. They used settle plates method for air samples, for other articles and surfaces swabs were taken. Sucker machine and OT air showed high bacteriological contamination. Besides, surfaces of OT showed less bacterial contamination. They finally

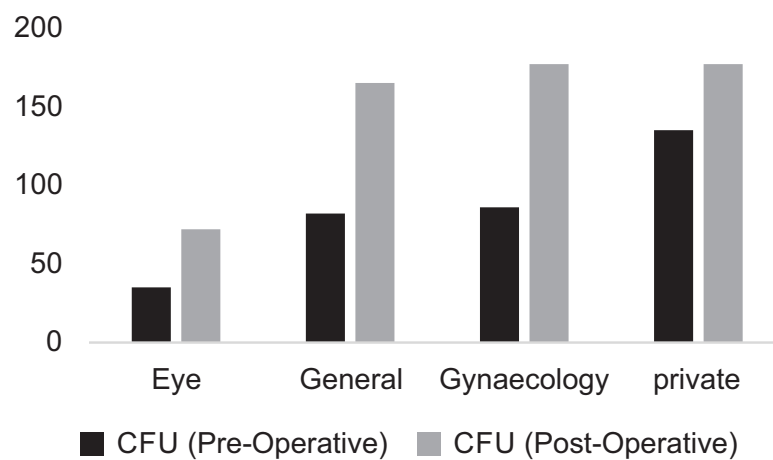

Figure-2. Mean CFU $/ \mathrm{m}^{2} / \mathrm{h}$ values for each theatre before surgery and during the last surgical procedure.

concluded microbiological surveillance play a very important role in the reduction of bacterial contamination and it will reduce postoperative infections.

Tesfaye, Berhe ${ }^{18}$ Studied that microbial contamination of the operating theater continued to increase the prevalence of nosocomial infections. There were five types of bacteria isolated with the highest prevalence of coagulase- 
negative Staphylococci (68; 53.5\%) followed by Staphylococcus aureus (42; 33.1\%). Methicillin resistance S. aureus (MRSA) accounts for $7.7 \%$ of the $\mathrm{S}$. aureus isolates. In general, the results indicate proper cleaning-fumigation of operating theater significantly reduced the microbial contamination, and bacterial strains such as CoNS and S. aureus have a greater propensity to cause contamination in OT. Therefore, efforts should be made to ensure strict infection control practices in the OT.

Mishra and Wadhai ${ }^{19}$ described the spread of bacterial contamination and its rate in operation theaters and they also find out how it contributes to the nosocomial infections of various hospitals of Wardha city (M.S), India. In this study, they collected samples for air open plate technique and swab method for surface and articles, and they further isolated and identified the bacterial types. The pathogens of bacteria like Staphylococcus spp. Coagulase-negative Staphylococcus spp. and Pseudomonas spp. were found. In the samples of air in Operation Theater, bacterial contamination was very high.

Al-Abbas $^{20}$ Conducted a study in Bayero University Kano, Nigeria. The isolates of clinical importance observed were Coagulase Negative Staphylococcus (COANS) spp. (34.5\%), P. aeruginosa (26.2\%), Non-hemolytic Streptococcus spp. (14.5\%), Proteus mirabilis (10.3\%), E. coli (8.3\%), S. cholerasius (4.1\%) and Staphylococcus aureus (2.1\%). The pattern of bacteria most frequently isolated was similar in the three operating theaters. Constant disinfection of surfaces and theater items under a strict infection control policy will check the transmission of infectious agents from these sources.

Johnson, Adekunle ${ }^{21}$ Studied that indoor air contamination of the operating theaters is one of the major sources of life-threatening nosocomial infections for patients undergoing certain surgical procedures. Airborne microbial samples were collected using the gravitational method and the total bacterial counts (TBC) and total fungal counts (TFC) per cubic-meter were determined before and after surgery. Indoor TBC and TFC after surgery was significantly higher than before surgery. Staphylococcus spp. and Aspergillus spp. were one of the bacteria and fungi species isolated respectively. The study implicated the indoor environment of the operating theaters as a source of contamination.

\section{CONCLUSION}

There is a high hazard for the occurrence of surgical site infections because of the significant level of pollution observed in our study. The results emphasize the need for proper cleaning, scrubbing techniques, improved disinfection and sterilization methods and regular fumigation of operation theatres to prevent the cause of infection and maintain a safe environment for the patients and health care professionals.

\section{Copyright(C) 08 Jan, 2020.}

\section{REFERENCES}

1. Anjali K, Anamika V, Mrithunjay K, Dalal A, Kumar A. Environmental microbiological surveillance of operation theatres in a Tertiary Care Hospital. Int $\mathrm{J}$ Cur Res 2015; 7(03): 13977-80.

2. Najera DK, Malhotra AS, Slathia P, Raina S, Dhar A. Microbiological surveillance of operation theatres: Five-year retrospective analysis from a Tertiary Care Hospital in North India. International Journal of Applied and Basic Medical Research 2017; (3): 165.

3. Montagna MT, De Giglio O, Cristina ML, et al. Evaluation of Legionella air contamination in healthcare facilities by different sampling methods: An Italian multicenter study. International journal of environmental research and public health $2017 ; 14(7): 670$.

4. Abdullah IM, Mohammed HN, Mansour SA. The effect of applying the international guidelines for clean surgery on infection control of patient's close intimate environments. Science Journal of University of Zakho 2017; 5(2): 147-53.

5. Kiranmai S, Madhavi K. Microbiological surveillance of operation theatres, intensive care units and labor room of a Teaching Hospital in Telangana, India. International Journal of Research in Medical Sciences 2016; 4(12): 5256-60.

6. Yadav M, Pal R, Sharma SH, Khumanthem SD. Microbiological surveillance of operation theatre in a Tertiary Care Hospital in North East India. International Journal of Research in Medical Sciences 2017; 5(8): 3448-53. 
7. Pirsaheb M, Sohrabi Y, Yarmohammadi H. Assessment of thermal comfort in hospital wards of Kermanshah, Iran, based on the standards. Executive Editor 2017; 8(2): 2357.

8. Solomkin JS, Mazuski J, Blanchard JC, Itani KM, Ricks P, Dellinger EP, Allen G, Kelz R, Reinke CE, BerriosTorres SI. Introduction to the Centers for Disease Control and Prevention and the Healthcare Infection Control Practices Advisory Committee guideline for the prevention of surgical site infections. Surgical infections. 2017 May 1;18(4):385-93.

9. Onwubiko NE, Akande AO. Microbial contamination in the operating theatre of a tertiary health institution in Kano, Northwestern Nigeria. Nigerian Journal of Microbiology. 2015;27(1):2671-9.

10. Berríos-Torres SI, Umscheid CA, Bratzler DW, Leas B, Stone EC, Kelz RR, Reinke CE, Morgan S, Solomkin JS, Mazuski JE, Dellinger EP. Centers for disease control and prevention guideline for the prevention of surgical site infection, 2017. JAMA surgery. 2017 Aug 1;152(8):784-91.

11. Chiguer M, Alami Z, Lamti S, Abda N. Prevalence and risk factors of healthcare-associated infections in a Moroccan teaching hospital. Canadian Journal of Infection Control. 2018 Dec 1;33(4).

12. Gupta S, Gupta N. Microbiological scrutiny of operation theatre in multi- speciality hospitals in gwalior, madhya pradesh, global journal for research analysis. 2019 Vol8:(5); 40-41

13. Banerjee $T$, Mishra A, Das A, Sharma S, Barman $H$, Yadav $G$. High prevalence and endemicity of multidrug resistant Acinetobacter spp. in intensive care unit of a tertiary care Hospital, Varanasi, India. Journal of pathogens. 2018 Jul 2;2018.
14. Saha $R$, Agarawal $S$, Khan AM. Air sampling procedures to evaluate microbial contamination: $A$ comparison between active and passive methods at high-risk areas in a Tertiary Care Hospital of Delhi. J Patient Saf Infect Control. 2017 Jan 1;5:18-23.

15. Saleem M, Ahmad I, Alenazi F. Incidence of clinical isolates and its antimicrobial resistance pattern among the nasal and hand swabs of operation theatre staff in tertiary and secondary care hospitals. Biomedical Research. 2018;29(18):3408-14.

16. Al Laham NA. Distribution and antimicrobial resistance pattern of bacteria isolated from operation theaters at Gaza strip. Journal of Al Azhar UniversityGaza (Natural Sciences). 2012;14(1):19-34.

17. Qaisar A, Akhtar N, Akhtar R, Latif W. Antimicrobial susceptibility profile of bacterial pathogens in surgical site infections at a Tertiary Care Hospital in Rawalpindi. Pakistan J Inf Mol Biol 2015; 3(3): 57-61.

18. Tesfaye T, Berhe $\mathrm{Y}$, Gebreselassie K. Microbial contamination of operating Theatre at Ayder Referral Hospital, Northern Ethiopia. International Journal of Pharma Sciences and Research (IJPSR) 2015; 6(10).

19. Mishra AK, Wadhai VS. Sterility testing of operation theatres in Hospitals. Int $\mathrm{J}$ Curr Microbiol App Sci 2016; 5(5): 440-7.

20. Al-Abbas AK. Aerobic bacteria isolation from the post-cesarean surgical site and their antimicrobial sensitivity pattern in Karbala City, Iraq. Iraq Medical Journal 2017; 1(4).

21. Johnson OO, Adekunle GF, Adenike A, Elizabeth TS, Sylvia ME, Olayinka MB. Indoor airborne microbial burden of operating theatres in a Tertiary Hospital in South-Western Nigeria. Int J Curr Microbiol App Sci 2017; 6(9): 3335-45.

\begin{tabular}{|c|c|c|c|}
\hline \multicolumn{4}{|c|}{ AUTHORSHIP AND CONTRIBUTION DECLARATION } \\
\hline Sr. \# & Author(s) Full Name & Contribution to the paper & Author(s) Signature \\
\hline 1 & Sobia Noreen & 1st Author & b.s. \\
\hline 2 & M. Ibrahim Yamin & 2nd Author & Thalluoyoun \\
\hline 3 & Ayesha Ajmal & 3rd Author & types. \\
\hline 4 & Muhammad Ajmal & 4th Author & u. Apulh \\
\hline
\end{tabular}

